33 Sundquist K, Frank G, Sundquist J. Urbanisation and incidence of psychosis and depression: follow-up study of 4.4 million women and men in Sweden. Br J Psychiatry 2004; 184: 293-8.

34 Mortenssen $\mathrm{PB}$, Pedersen $\mathrm{CB}$, Melbye $\mathrm{M}$, Mors $\mathrm{O}$, Ewald $\mathrm{H}$. Individual and familial risk factors for bipolar affective disorders in Denmark. Arch Gen Psychiatry 2003; 60: 1209-15.

35 Freeman D, Garety PA. Connecting neurosis and psychosis: the direct influence of emotion on delusions and hallucinations. Behav Res Ther 2003; 41: $923-47$
36 Freeman D, Gittins M, Pugh K, Antley A, Slater M, Dunn G What makes one person paranoid and another person anxious? The differential prediction of social anxiety and persecutory ideation in an experimental situation. Psychol Med 2008; 38 $1121-32$

37 Ellett L, Freeman D, Garety P. The psychological effect of an urban environment on individuals with persecutory delusions: the Camberwell walk study. Schizophr Res 2008; 99: 77-84.

\section{Psychiatrists in 19th-century fiction}

\title{
In a Glass Darkly (1872), J. Sheridan LeFanu
}

\section{Fiona Subotsky}

Joseph Sheridan Le Fanu (1814-1873) is another literary Dubliner. Having studied law at Trinity College, he became a journalist and author, famous for both his sensationalist novels and his supernatural tales. For In a Glass Darkly Le Fanu used a technique common in gothic fiction by having a narrator/editor who presents past documents, in this instance of mysterious medical case histories from the papers of the nowdeceased Dr Hesselius. The latter is a European 'metaphysical physician' with Swedenborgian leanings who likes to investigate curious psychological phenomena. He considerably resembles the later Professor Van Helsing from Bram Stoker's Dracula.

In the story Green Tea, letters to a non-medical friend describe the case of the Rev. Mr Jennings whom Dr Hesselius meets first at a small soirée in London. The Reverend is a kind and pleasant man, but

"when he goes down to his vicarage in Warwickshire, to engage in the actual duties of his sacred calling, his health soon fails him, and in a very strange way ... it has happened three or four times, or oftener, that after proceeding a certain way in the service, he has on a sudden stopped short, and after a silence, apparently quite unable to resume, he has fallen into solitary, inaudible prayer, his hands and his eyes uplifted, and then pale as death, and in the agitation of a strange shame and horror, descended trembling, and got into the vestry-room, leaving his congregation, without explanation, to themselves.'

Dr Hesselius notes a strange quirk:

'Mr Jennings has a way of looking sidelong upon the carpet, as if his eye followed the movements of something there. This, of course, is not always. It occurs now and then. But often enough to give a certain oddity, as I have said, to his manner."

The two talk, and Dr Hesselius promises to pass to Mr Jennings a copy of his book Essays on Metaphysical Medicine, which the latter is eager to re-read. Subsequently, rather in the manner of a later medical sleuth, Sherlock Holmes, Dr Hesselius amazes his hostess by surmising correctly that Mr Jennings is unmarried, that he had been writing a book, but stopped, and that he 'extravagantly' liked green tea, but has given it up. Subsequently Dr Hesselius visits Mr Jennings, and as he is engaged with a visitor, is shown into his library. There he picks up a volume by Swedenborg, annotated by Jennings, which includes the comments:

'When man's interior sight is opened, which is that of his spirit, then there appear the things of another life ... Evil spirits (may) present themselves, by "correspondence," in the shape of the beast . . . which represents their particular lust and life, in aspect direful and atrocious.

Mr Jennings asks for a professional medical consultation, as he has been disappointed by the materialist approach of a Dr Harley, and tells his story. He had been studying deeply in an attempt to write a book on 'the religious metaphysics of the ancients', and in doing so often worked late into the night imbibing large quantities of green tea. He noticed no ill effects until he became aware of the repeated presence of a small black monkey, with glittering eyes, who regarded him malevolently; and now the animal has become even more intrusive, making blasphemous remarks when he attempts to pray and perform his religious duties.

Dr Hesselius advises that 'in your case ... the veil of the flesh, the screen, is a little out of repair, and sights and sounds are transmitted' but that the 'thing that infests you ... can have no power to hurt you, unless it be given from above'. However, he would give the matter careful thought.

At a later consultation, Mr Jennings' experiences have worsened. The terrifying monkey has recently ordered him to throw himself down a mine shaft, a command he was only able to resist as he was accompanied by his niece. Again Dr Hesselius assures him that the cause must be physical, and that he should not, as he seems to, believe that he had 'been delivered over to spiritual reprobation'.

Unfortunately, Dr Hesselius' risk assessment has been weak, and the next time he is called his patient has been found dead, having cut his own throat. He reflects on the case to his correspondent, and concludes he has not been at fault. First: ' I have met with, and treated, as my book shows, fifty-seven cases of this kind of vision ... And in how many of these have I failed? In no one single instance'. He explains the mechanism by which the 'inner eye' is opened: nervous fluid, which is 'spiritual, though not immaterial' may be disturbed in its equilibrium by substances such as green tea, and form 'a surface unduly exposed, on which disembodied spirits may operate'. Such a condition may be remedied by the application of cold, such as 'iced eau-de-cologne'. However, in this case he had not yet advanced to treatment.

\section{Furthermore:}

'Poor Mr Jennings made away with himself. But that catastrophe was the result of a totally different malady, which, as it were, projected itself upon the disease which was established ... the complaint under which he really succumbed, was hereditary suicidal mania.'

The real life medico-psychologist Henry Maudsley had of course a different view of Swedenborg, whom he considered to have chronic mania, perhaps also with epilepsy. As a materialist, he might well have agreed with Hesselius's final diagnosis, whereas we, the readers, remain unnerved by the thought of the inescapable malevolent simian. 